\title{
Changes in the Landscape
}

\author{
Enrico Kalb
}

\section{Introduction}

In view of globally increasing "landscape use" due to new development, roads and forest clearance to create new agricultural areas, natural areas are subject to extreme change. Studies of land use change are thus becoming increasingly important.

The area under investigation is located on the northeast coast of Bali, for whose components a lasting anthropogenic settlement and, subsequently, a reshaping of the landscape by the people is already evident. The origins of the reshaping of the landscape and its vegetation in the last century will be examined in the study through general physiographic work processes with regard to vegetation. In addition to pedogenic and geological considerations, a three-dimensional figure of the globe's surface will also be used.

\section{Physiographic Aspects}

\section{Introduction and Land Form}

Approximately $102 \mathrm{~km}^{2}$ in size, the area under investigation is located on the northeast coast of Bali and belongs to the districts (kabupaten) Buleleng and Bangli. It is situated approximately $30 \mathrm{~km}$ east of the centre of the former harbour town 
of Singaraja and covers parts of the sub-districts (kecamatan) Kubutambahan and Tejakula (Figure 1 in the Introduction to this volume).

The fringe threshold of the north-eastern region of Bali is divided into two parts running from north to south (Figure 1).

The coastal plain runs northwards into the Bali Sea and shows soil rich in nutrients at a low inclination of $1^{\circ}$ to $3^{\circ}$ (occasionally a maximum of $5^{\circ}$ ) with coarse sand. Its low relief is partly responsible for the presence of main roads with numerous towns and villages on the coastal strip. Moreover, the coastal plain offers a good location for horticulture, as the low sea-level in connection with a high ground-water level facilitates irrigation all the year round through self-dug wells.

The transition from coastal plain to mountain area is usually very abrupt and characterised by savannah landscape which runs up to the gardens of the settlements.

The mountain area constitutes a rather steady rise next to the deeply carved mountain range of the Ayung Valley to the east of the area under investigation with an average inclination of 13 degrees and a relief increase of 1.000 metres. This inland rise is determined by the second largest and active volcano (Batur $1.712 \mathrm{~m}$ above sea-level) whose lava fields and ash rain settle in the region. Small plateau fields and deep valley forms with retrogressive erosion mark the morphological shape of the area.

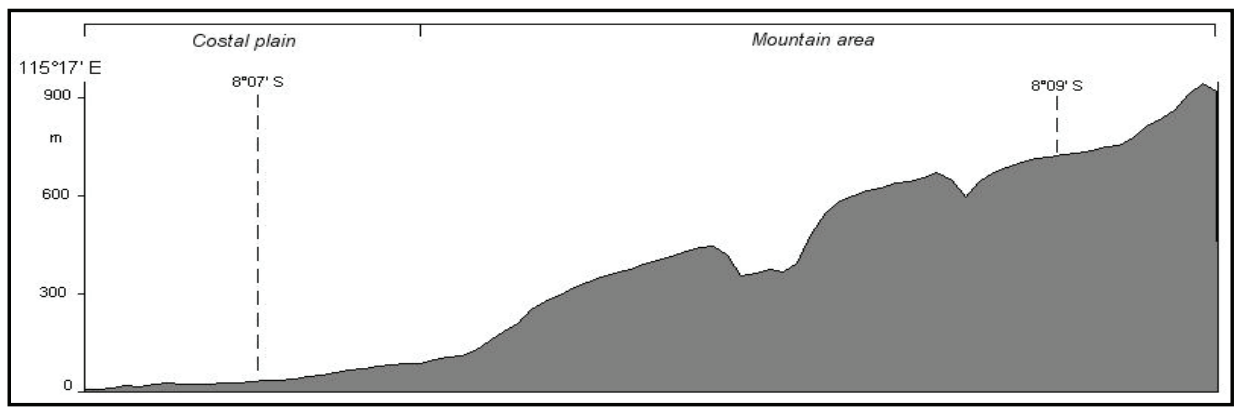

Figure 1: N-S profile of the area under investigation on the geographic longitude of $115^{\circ} 17^{\prime} \mathrm{E}$.

\section{Climate}

The tropical monsoon climate is affected by the monsoon winds, which shows a diurnal climate in which the temperature fluctuations within a year move below those of a day. The air temperature reaches on average approximately $26^{\circ} \mathrm{C}$ in altitudes below $500 \mathrm{~m}$ above sea-level. Changes in temperature take place with increasing altitude, where the air mass cools below the saturated adiabatic lapse rate of $0,6 \mathrm{~K}$ per $100 \mathrm{~m}$ (Whitten et al. 2000). 
With approximately 1.700 to $1.800 \mathrm{~mm}$, the annual amount of precipitation for the north-eastern area of Bali is low compared to most other regions of Indonesia, which have 2.000 to $3.000 \mathrm{~mm}$ (Domrös 1979). Figure 2 illustrates the crucial role of macrorelief in the distribution of precipitation in and around the area under investigation. The unequal distribution of the values depends upon the orographic rise of air mass and the associated precipitation of the surplus water in the cooled air and through air mass convergence, convection of high equatorial radiant intensity and local wind convergence in the mountain range.

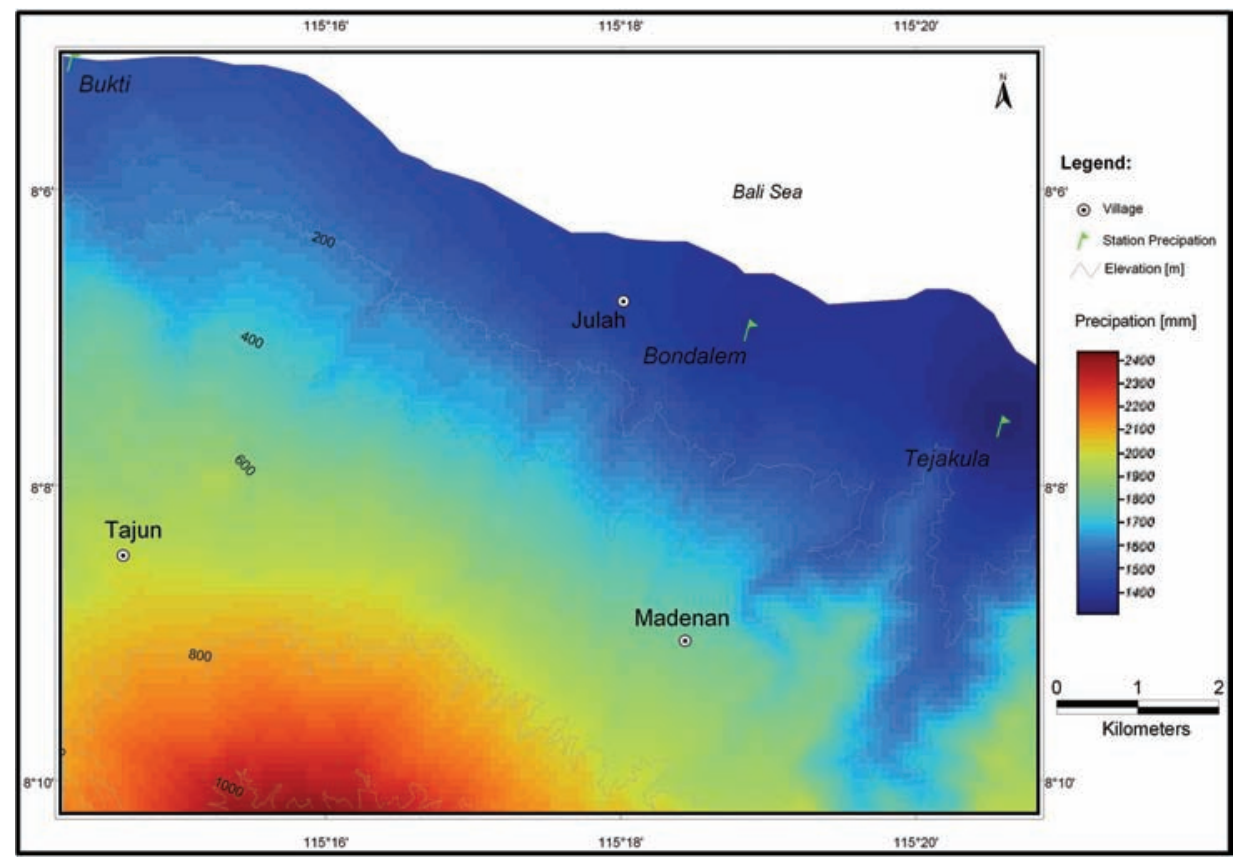

Figure 2: The map depicts the average and classified annual figures for precipitation from 1983 to 2000. The values were calculated in association with the regressive rise of the ground level using the spatial-stochastic interpolation process "kriging".

\section{Soil}

The in-situ volcanic rocks in the area under investigation form a good basis for the emergence of nutritious soil and, thus, the cultivation of agricultural areas. Falling of recurrent ash rain (Uhlig 1979) from the nearby volcanoes Batur and Agung has also contributed recently to the mineralization of the soil. The prevailing soil type is confined to regosol according to the FAO classification (Food and Agriculture Organization of the United Nations) (Schmidt 1979), and consists therefore of soil that contains more than $20 \%$ of volcanic loose masses as source 
material or higher proportions of allophanes (sorption-heavy clay minerals). The porousness and good permeability of the soil, as well as its large nutrient reserves, ensure high fertility.

The river valleys and flat coastal sections are distinguished by alluvial and lahar soil (mud stream of water and ash arising in volcanic eruptions). The superficial close lahar soil in the north-eastern coastal region comes primarily from an alluvial complex composed of volcanic materials (andesite, volcanic breccia, tuff and ash) (Eelaart 2003). Drilling carried out by the Institute "Sustainable Development of Irrigated Agriculture in Buleleng and Karangasem" showed that the alluvial fans in the coastal area on average reach sizes between 1 and 25 metres. The soil types of the fluviatile sediments fluctuate between sandy loam and clay stone with a coarse texture. Inland, the fans gradually decrease in proportion to inclination of the relief and the relative altitude to the sea. In addition to the frequently occurring regosols, fluvisol soil and, on the coast, occasionally cambisol soil were also categorised in the area under investigation (Eelaart 2003).

\section{Geology}

The active volcano Batur, which borders the area under investigation and has been in existence for approximately 500.000 years (Sutawidjaja 1990), contributes considerably to the prevailing subterranean conditions of the area up to this day. As we can gather from the geological map (Figure3), the largest area is occupied by volcanic rock. The andesitic-basaltic igneous rocks of the volcanoes Buyan and Bratan, situated to the southwest, and the south-eastern Batur volcano are classified as belonging to the Holocene Period in the geological time scale (100.000 to 60.000 years ago).

The combination of several forms of chemical and physical weathering in the subtropical and tropical latitudes has led to the genesis of a loose mass blanket in the area just below the surface. These weathering products and, at the same time, sediments are subject to fluvial erosion and fluvial accumulation in the rain season. The accumulation takes place primarily in the coastal area or directly in the sea.

The weathering products of this constantly visible process are referred to as $\mathrm{Q} a$ and are among the youngest geological phenomena in the area under investigation. The volcanic rocks with the name Qvbb can be attributed to an eruption of the Buyan-Bratan volcanoes during the mid-Pleistocene period (approx. 500.000 to 1,3 mn. years ago). They are made of volcanic breccia and extrusive rocks with enclosed tuff. They belong to the Asah formation, which characterises the coastal area from Bondalem to Bukti. The formation arose in the Pliocene Period (approx. 1,6 to $5 \mathrm{mn}$. years ago). 


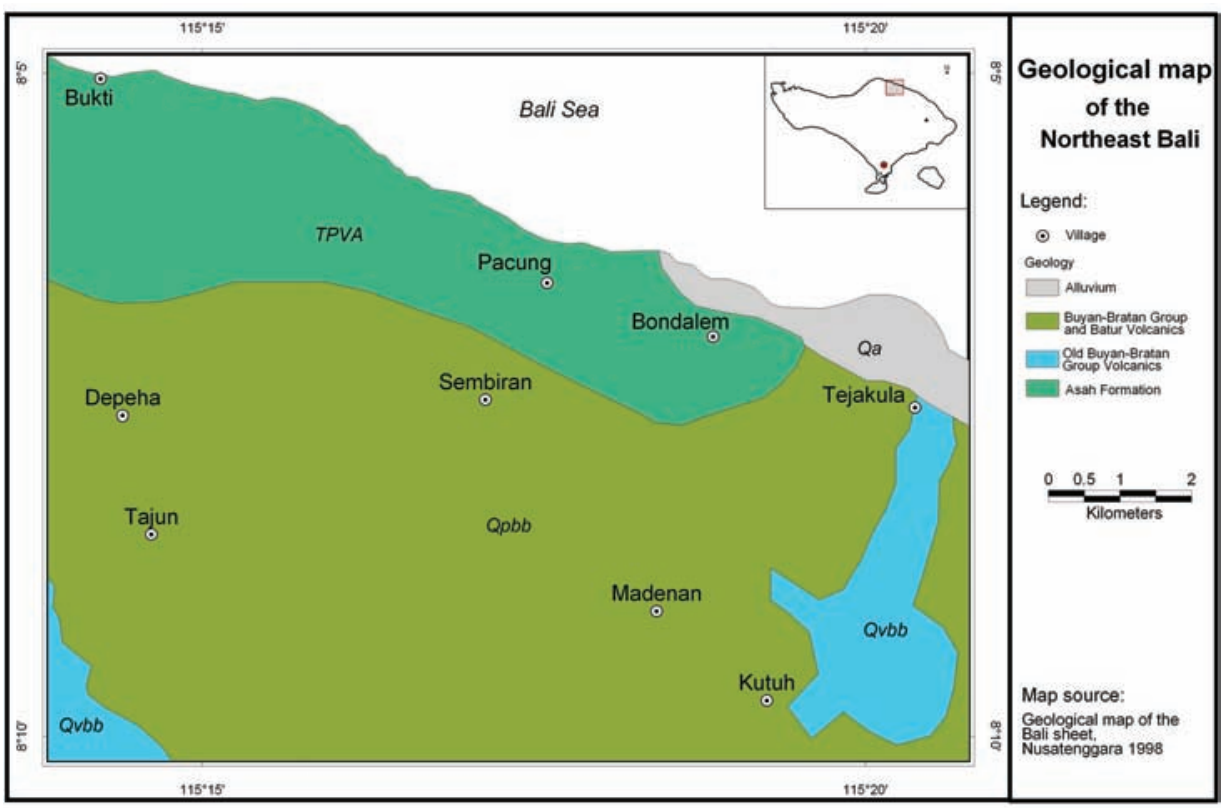

Figure 3: Geological map of the area under investigation (altered according to GRDC 1998).

\section{Investigative Methods and Data Basis}

The extensive registration of the landscape change in the area under investigation is carried out using two periods (1923 and 2004), for which precise map resources were made available. For the first period, maps were used dating from the years 1923 to 1925 during the Dutch colonial era. As the Dutch at that time were mainly interested in profitable export goods such as rubber, coffee, tea and sugar, comprehensive land use was recorded on the maps. Furthermore, detailed information regarding the size of settlements, individual locations and altitude are illustrated in the specimens available as colour prints drawn to a scale of 1:50.000.

The topographical maps from the institute BAKOPSURTANAL (Badan Koordinasi Survey dan Pemetaan Nasional) from Jakarta, drawn to a scale of 1:25.000, formed the data basis for the second period. The maps were reprinted in 1999. Aerial photographs from 1993/94, which were processed photogrammetrically to a scale of 1:50.000 and combined with field photographs from 1999 served as a basis. In order to make the present comparison of the two periods 1923 and 2004, high-resolution pictures were ordered from the QuickBird sensor of DigitalGlobal $^{\odot}$ on 1. September 2003. The sensor provides the data in two different types of picture. The first is with a 2,44 to $2,88 \mathrm{~m}$ resolution in a three-channel 
multispectral mode and close-up, infrared. The second photograph is carried out in black and white mode (panchromatic mode) with a resolution of 0,61 to $0,72 \mathrm{~m}$.

The data available for each period was converted into digital form using the software PCI Geomatica ${ }^{\odot}$ and geo referenced.

Mapping of the types of land use was carried out for each period using the geographic information system ArcGIS 9.0 . The pre-processed multispectral satellite picture was classified beforehand by means of an unattended classification using the software ENVI $4.0^{\circ}$. The land use map produced was tested and improved on site through a sampling procedure in minimum areas of a 0,1 ha surface, and vegetation units could be assigned to the spectral values. This led to a formulation of the vegetation complex, characterised floristically through dominant species. Afterwards, the area percentages were calculated. Moreover, in order to obtain a more differentiated analysis of the area, a construction of the Digital Terrain Model (DTM) was carried out, which related to the geomorphological units, such as inclination, elevation and exposure.

Written sources - primarily statistic year books of the CKS (Central Kantoor voor de Statistiek van het Department van Economische Zaken) - verbal records and earlier photographs facilitated chronological classification and clarification of the causes of the changes established.

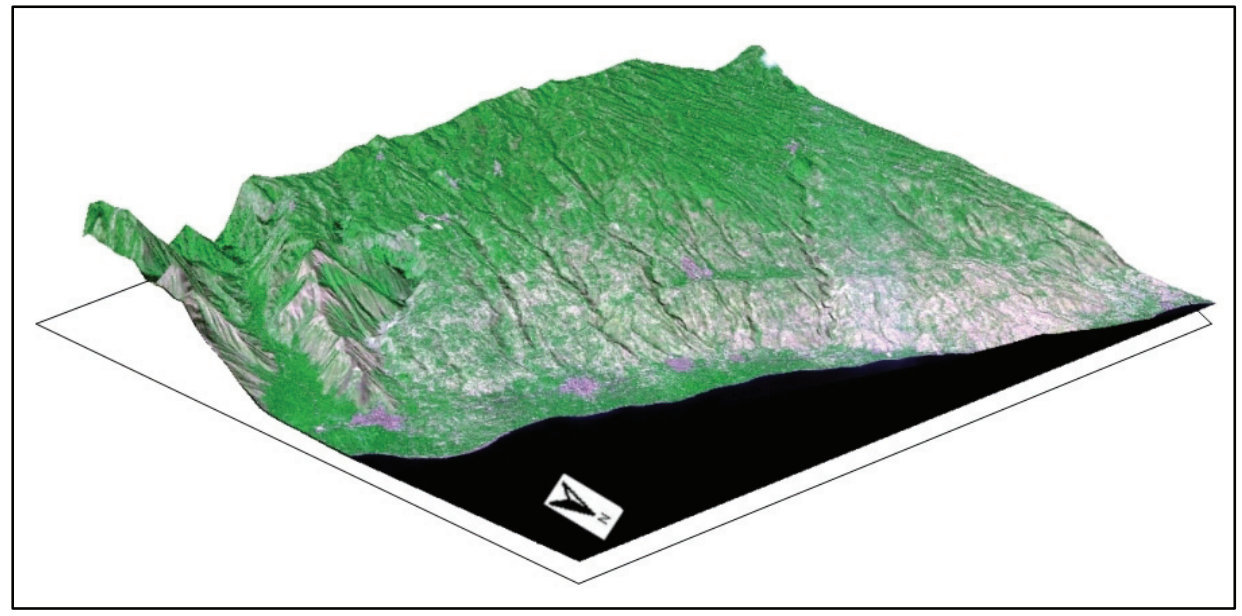

Figure 4: Three-dimensional representation of the area under investigation with triple transversal slopes. 


\section{Results}

\section{Land Use Analyses by Means of a Satellite Picture and Mapping}

The botanic examination concentrated on an analysis of the occurring vegetation ratios in the area under investigation. At the same time, the structures of the habitats were analysed for their floristic compositions and frequency, and in this way the significance of individual plant types in each habitat was established.

Two gradients were recognised as landscape-defining for the area under investigation, based on the interpretation of the satellite picture: a north-south gradient, reflecting the influence of the high altitude climate, and an east-west gradient, caused by the anthropogenic intervention of the irrigation canal built in the area of the Ayung Valley (south Tejakula). The coastal road, which follows the direction of the east-west gradient, was chosen as a starting position for the areas of investigation situated further away. The locations of these areas depended upon the previously classified vegetation complexes and the degree of availability (Kalb 2006).

On the basis of classification made with the help of the processed satellite picture and later verification during field work, nine land use categories could be distinguished. Seven of the nine land use categories were considered to be vegetation categories; the categories Settlement and Vegetation-free have to be considered separately. In the case of Settlements, areas are meant that are sealed off by development (houses, streets etc.). Vegetation-free areas are characterised by their relief conditions. In the higher and steeply sloping regions, the soil erosion is so high that no soil development can build up sufficiently to support a vegetation layer.

Figure 5 illustrates the result of the land use mapping made possible by the QuickBird scene and the field photographs. The elevation classes marked in colour on the map reflect the cultivation of high altitude-climatic plant communities. 


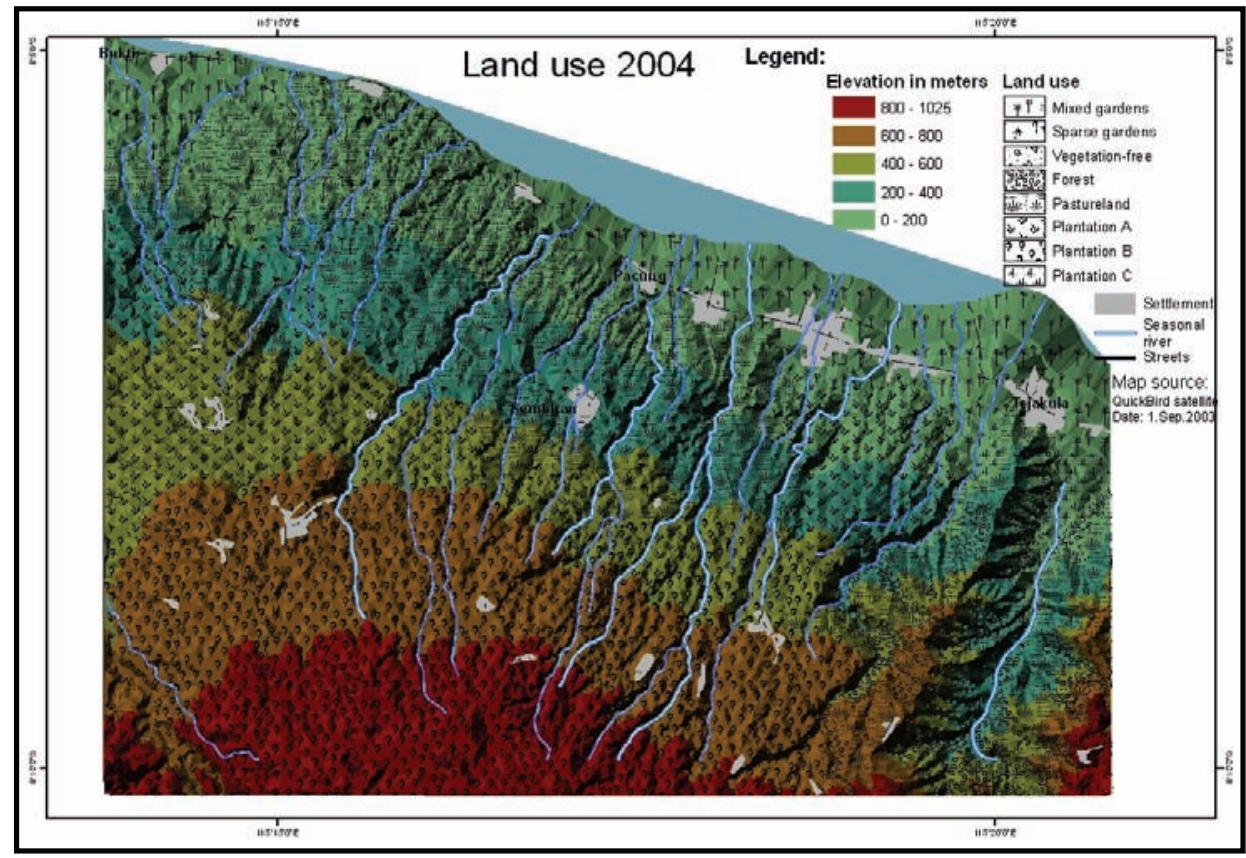

Figure 5: The land use of the region under investigation in 2004 with information on elevation.

\section{Land Use Analysis from Historical Maps}

For the historical land use classification, topographical maps were implemented ${ }^{1}$, the age and origin of which are mentioned in above. After the preparation of the charts, they were compared with the satellite picture with integrated criteria. In the interpretation of the historical charts, very precise cartography could be identified. Differences arise primarily in the names of settlements or rivers that differ from the current ones.

The symbols included in the historical charts illustrate the prevailing vegetation of the time extensively. Scale settlements with detailed information also appear in them.

For the classification of land use, the dense, point-like symbols have to be projected in areas from the analogue chart. The borders of the vegetation units were interpolated visually with GIS using these symbols. Six units of land use were recorded here categorized as Mixed gardens, Plantation coffee, Sparse gardens,

\footnotetext{
${ }^{1}$ For the evaluation of historical land use analyses, remote sensing records provide a better basis than historical charts. Research based on aerial photographs or similar techniques remained inconclusive. The historic charts provide the only freely available access to bygone vegetation.
} 
Settlements, Vegetation-free and Savannah. The figure below illustrates the area under investigation with the vegetation as it was in 1923, when the topographic maps were drawn.

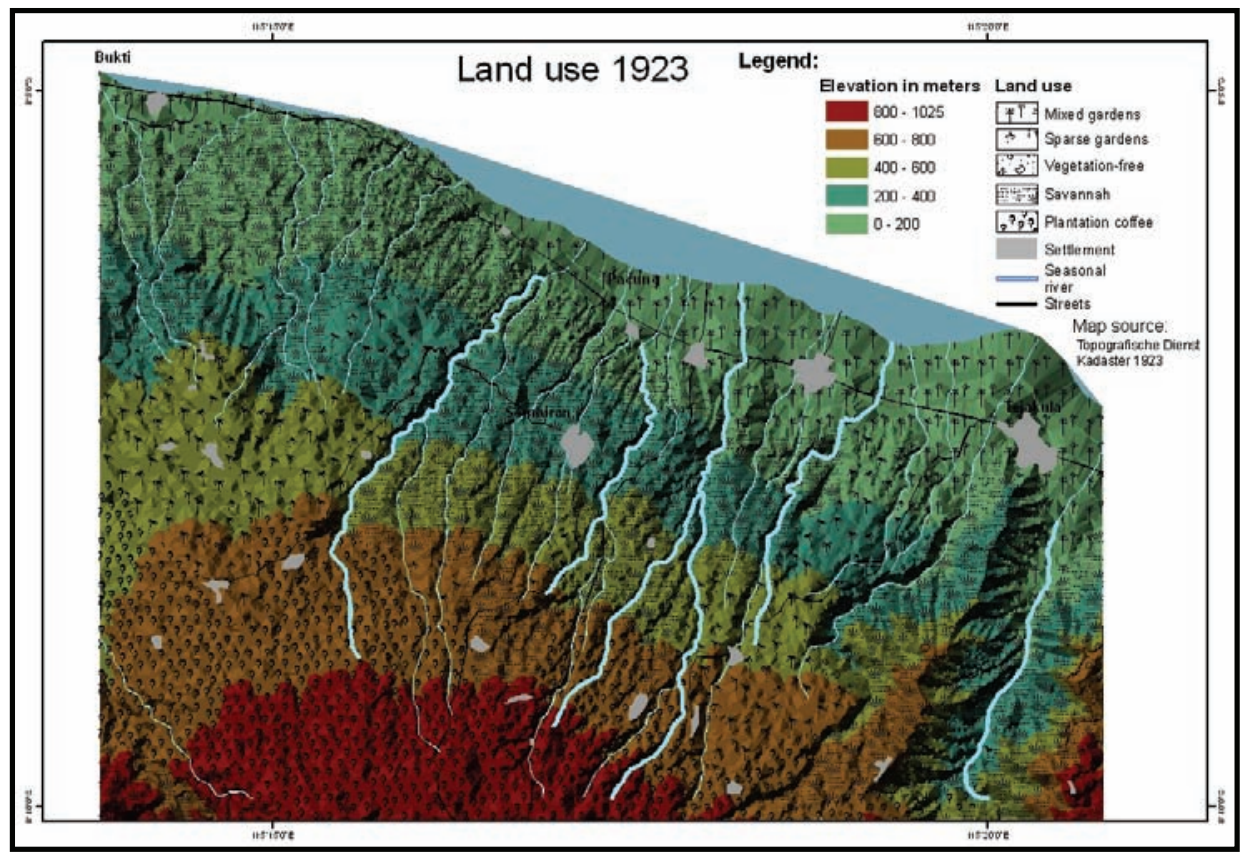

Figure 6: The land use of the region under investigation in 1923 with information on elevation.

\section{Accuracy Evaluation of the Vegetation Analysis}

In any current evaluation of historical data for the purpose of a historical landscape analysis, one can assume that it involves data that are not optimal for the purpose of evaluation. Although the maps made available in this study contain informative evidence of land use, they also conceal many details in the reproduction scale which can be emphasised in the QuickBird scene of 2003 with a soil resolution of $0,6 \mathrm{~m}$.

In the registration of changes in the landscape, there is also a lack of available material for the cartographers with regard to content. Consequently, unclear distinguishable objects are represented by sharp borders. In addition, geometric errors have to be taken into account in the registration of objects on an evaluation board.

The characteristics of land use in the historical maps are based upon symbols which usually only express individual plant genera. These could only be inter- 
preted and classified by adopting an approach according to the principle of relevance regarding today's vegetation. The results of the areas have to be viewed critically due to the interpolation and the actualistic principle; nevertheless, the area percentages of the individual classes in the overall picture and their changes within the period are relevant compared to the general development of the island state of Indonesia.

\section{Change Detection}

According to Myint (2001), change detection is the registration of changes, and therefore a process in which the difference of a single object is identified and investigated through observations at different times.

To enable interpretation of the change in land use by means of the multitemporal QuickBird scene and the maps supplied in the period of 1923 to 2003, both pictures were classified. The following addition was also made. The previously investigated land use categories from both pictures were standardised to facilitate a representative comparison. This resulted in the amalgamation of the categories Plantation A, B, C and Plantation coffee as "Plantation" and Forest and Savannah as "Savannah". All of the other classes retained their original name.

The arithmetical results of the comparison of the area percentages of the individual classes of both periods are illustrated in Table 1 and Diagram 1. The result of both classifications was illustrated in Figure 7 through the intersection of all categories with GIS.

Table 1: Percentage Comparison of the Land Use Shares between 1923 and 2003

\begin{tabular}{|l|l|l|l|}
\hline Class & $\begin{array}{l}\text { Share in \% } \\
1923\end{array}$ & $\begin{array}{l}\text { Share in \% } \\
2003\end{array}$ & Balance in \% \\
\hline Mixed gardens & 13.77 & 10.65 & -3.12 \\
\hline Rivers & 3.10 & 2.82 & -0.28 \\
\hline Roads & 0.24 & 0.72 & 0.48 \\
\hline Plantations & 23.70 & 47.38 & 23.68 \\
\hline Settlements & 1.26 & 2.07 & 0.81 \\
\hline Sparse gardens & 16.43 & 3.08 & -13.35 \\
\hline Vegetation-free & 1.42 & 1.18 & -0.24 \\
\hline Savannah & 40.08 & 32.11 & -7.97 \\
\hline
\end{tabular}




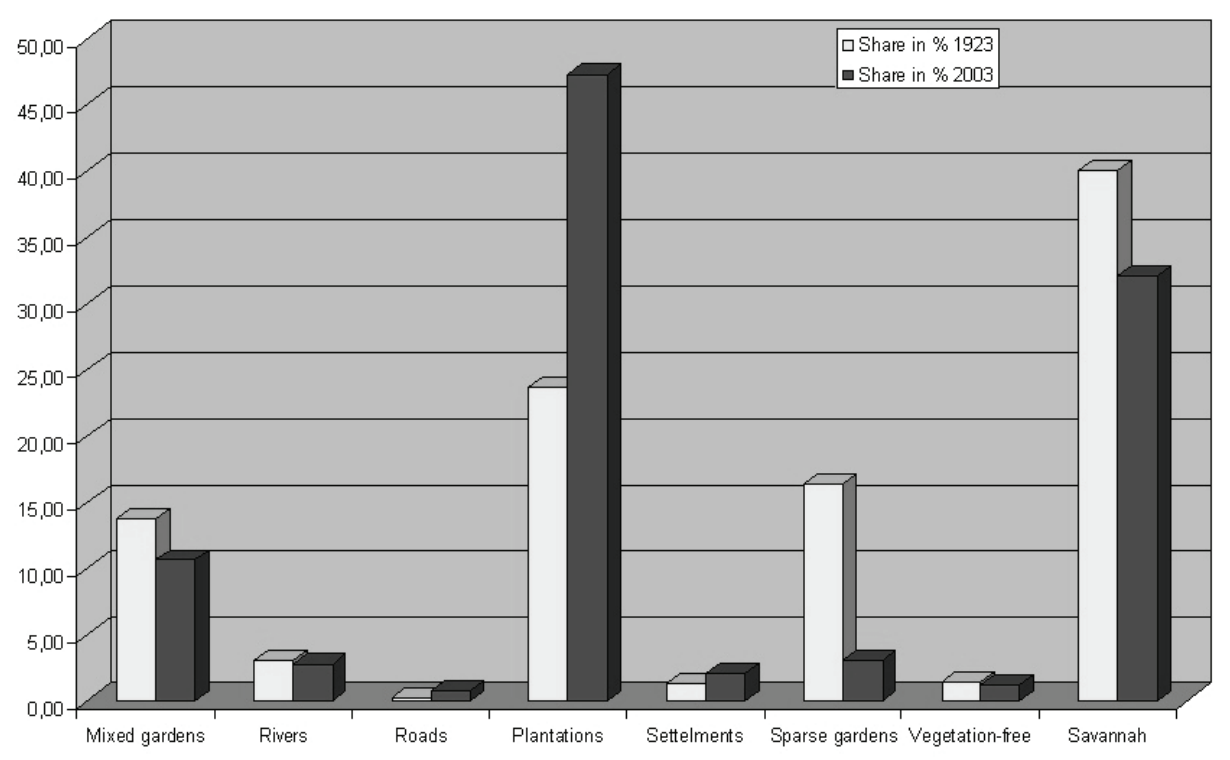

Diagram 1: Percentage comparison of land use proportions between 1923 and 2003.

\section{Interpretation and Discussion}

The results of the land use categories should be viewed critically as the surface shares do not serve as absolute numbers but rather as approximate values. The observations of the accuracy evaluation (see above) indicate that a precise classification is difficult. For this reason, classes where land use change is on balance below $1 \%$ are not examined more closely. However, in this study, significant errors in the land use classification cannot be assumed.

The category Plantation displays the clearest change within 80 years. It constitutes the second largest land use category in 1923 with 23,68\% and is the largest land use category in 2003 with an area percentage of 47,38\%. The growing demand for export agriculture, such as coffee, cocoa and cloves saw an increase in cultivation of $100 \%$ in small farming businesses within the period measured. According to the CKS (Central Kantoor voor de Statistiek van het Department van Economische Zaken) of 1938, the demand for products from the plantation business is extremely low compared to that of today. Not even a third of the few areas reserved for plantations were actually cultivated. 
The extent to which the cash crops of 1923 (within the plantations) differed from the present agricultural dominance could not be analysed in detail. However, it can be assumed that it was a homogenous coffee plantation in comparison to the mixed plantation of today as the coffee symbol is used exclusively in the historic maps.

It was clear from the current mapping that the areas of the plantations under cultivation are increasing. A significant extension of these areas has occurred in the east along the Madenan-Bondalem road. Furthermore, the cultivation of the cash crops to the west of the area under investigation has been extended around the village of Tunjung. The extension of both of these regions has occurred on former Sparse gardens. This also includes the plantations south of Tejakula, which were only laid out in the 1990s. The extension was mapped on a small scale in the centre of the area under investigation where cultivation took place on former savannah country.

The second largest land use change, with a deficit of $13,35 \%$, was analysed in the category Sparse gardens. It has been increasingly replaced by the cultivation of plantation agriculture in recent decades. The settlement of ethnic groups in the region can be named as a reason for the advance of cash crops in unfavourable locations, for which the expanding population and immigration on Bali has been responsible in recent decades. The statistics from 1930 substantiate this: 1.101 .393 inhabitants (CKS 1938), 1971: 2,120,322 inhabitants and 2000: 3.151 .162 inhabitants (http://www.bps.go.id 2005).

In the same way, the Savannah has shrunk also from $40,08 \%$ to $32,11 \%$. The following development can be seen in most areas: plantations have emerged today where Sparse gardens and Savannah could be found adjacent to each other in the 1920s. This kind of plantation can be classified without exception under the plantation A category presented here.

In the case of Mixed gardens, there is a negative balance of $3,12 \%$. This is the result of the loss of the gardens in the areas south of Bondalem to Pacung and the expansion of the gardens in the north-western area of the area under investigation. The land use change of Mixed gardens occurred on savannah landscapes, or was taken over by these. 


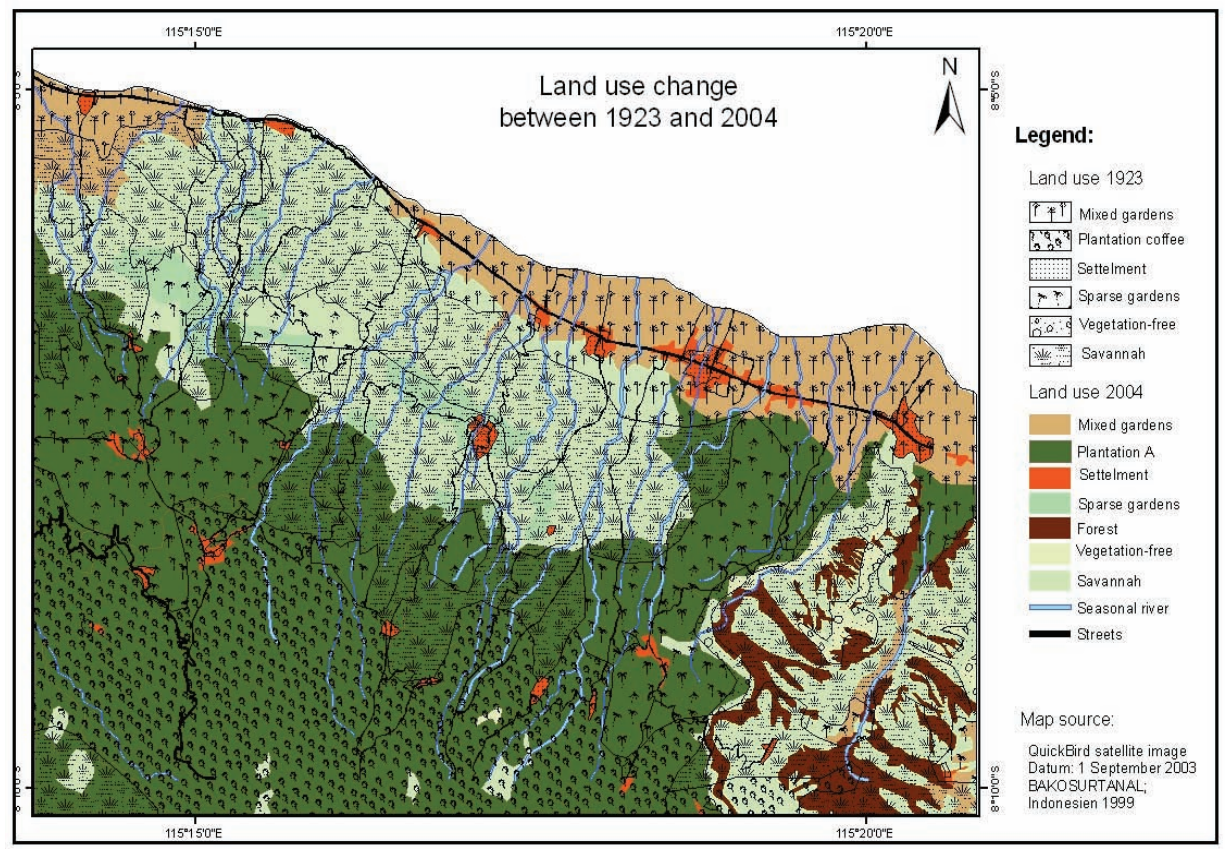

Figure 7: The land use change of the area under investigation between 1923 and 2004

\section{Summary}

In the existing study, a description of land use change between 1923 and the present was carried out for the area under investigation. To achieve this, a map including historical data from 1923 during the Dutch colonial period, botanical ground surveys from the summer of 2004 and high resolution satellite pictures from the sensor QuickBird ${ }^{\odot}$ on $1^{\text {st }}$ September 2003 were put together. For classification of the present land use, the QuickBird ${ }^{\odot}$ scene from the $1^{\text {st }}$ September was available. During the site visit in the summer of 2004, more detailed and informative data was recorded for the land use classification to be made. The historical data referred to for the differential analysis originate from the Dutch colonial period and provide good insights into the land use ratios around 1923 in the form of topographical maps. The available data records were subject to pre-processing and adapted to an integrated digital reference system. The investigated land use areas as seen on historical topographical maps could not be further checked and thus had to go into the classification from 1923. The results of both classifications were compared to using geographic information system, and changes in land use between the two periods were calculated. The land use classification produced 
eight categories which differed in their percentage area balance between 1923 and 2003 as follows: Mixed gardens $(-3,12 \%)$, Plantation $(+23,68 \%)$, Sparse gardens $(-13,35 \%)$,Vegetation-free $(-0,24 \%)$ and Savannah with Forest $(-7,97 \%)$. The categories Settlements, Roads and Rivers occupy the least significant area percentages in the area under investigation together with the category Vegetation-free. The result of the change detection shows the greatest changes within the plantations. With an area percentage of over $47 \%$, it presently represents the largest land use category in the area under investigation.

\section{References}

Bandan Pusat Statistika

2005 http://www.bps.go.id/index.shtml; (24.07.2005).

Central Kantoor voor de Statistiek van het Department van Economische Zaken

1938 Statistisch Jaaroverzicht van Nederlandsch-Indie over het Jaar 1936. Indisch Verslag, Batavia. In: Zimmermann, G.R. (2003): Indonesien: eine geographische Landeskunde; S. 157. Nackenheim: Ed. Matahari.

Domrös, $\mathrm{M}$.

1979 Klima-Niederschlag. In: Junghans, K.H. et al. (Hg.): Indonesien: Geographie, Geschichte, Kultur, Religion, Staat, Gesellschaft, Bildungswesen, Politik, Wirtschaft. Tübingen; S. 21-31. Basel: Horst Erdmann Verlag.

Eelaart, A. van den

2003 Mission Report of the Tropical Soils and Land Use Specialist. Sustainable Development of Irrigated Agriculture in Buleleng and Karangasem. Project IDN/RELEX/2001/0087; pp. 5-8. Singaraja.

Geological Research and Development Centre (GRDC)

1998 Geological Map of the Bali Sheet. Bandung.

Kalb, E.

2006 Erosionsmodellierung und Landnutzungsinterpretation der Küstenregion von Nordost Bali, Indonesien. Stuttgart: ibidem-Verlag.

Myint, O.

2001 Untersuchungen zur Anwendung von Satellitenfernerkundung und terrestrischen Aufnahmen zum forstlichen Monitoring und zur Planung im tropischen Regenwald, am Beispiel in Bago District in Myanmar. Göttingen: Cuviller.

Schmidt, H.L.

1979 Geologie und Lagerstätten. In: Junghans, K.H. et al. (Hg.): Indonesien: Geographie, Geschichte, Kultur, Religion, Staat, Gesellschaft, Bildungswesen, Politik, Wirtschaft; S. 7-14, 24-29, 44-58. Tübingen, Basel: Horst Erdmann Verlag. 
Sutawidjaja, I.S.

1999 Gunung Batur. Berita berkala Vulkanologi. Edisi Khusus, Direktorat Vulkanologi, No. 158.;

http://www.vsi.esdm.go.id/gunungapiIndonesia/batur/geologi.html; (24.07.2007).

Uhlig, $\mathrm{H}$.

1979 Oberflächeform und Böden. In: Junghans, K.H. et al. (Hg.): Indonesien: Geographie, Geschichte, Kultur, Religion, Staat, Gesellschaft, Bildungswesen, Politik, Wirtschaft; S. 7-14, 24-29, 63-64. Tübingen, Basel: Horst Erdmann Verlag.

Whitten, T., Soeriaatmadja, R. and S. Afiff

2000 The Ecology of Java and Bali. The Ecology of Indonesia Series, Vol. II: 117-128.

Singapore: Periplus. 